\title{
Identification of Competitive Strengths 5 Best Marketplace in DKI Jakarta
}

\author{
$\underline{\text { Alma Kurniawan }}{ }^{1}$, Rudy C. Tarumingkeng ${ }^{2}$, Gidion P. Adirinekso ${ }^{3}$ \\ 1,2,3 Faculty of Economic and Business, Krida Wacana Christian University, Indonesia \\ Email:almaniak22@gmail.com
}

\begin{abstract}
:
Increasingly competitive competition arises because of digital technology in business. One of Michael Porter's famous competitive theories is regarding the competitive force. There are five components in it: bargaining power of customers, bargaining power of suppliers, the threat of new entrants, threat of substituted products and services, and rivalry among existing competitors. Using quantitative methods, this study will discuss Michael Porter's theory components that affect business competition in the digital era. The sample selection for this research is spread over all people of DKI Jakarta who have at least one marketplace. According to the seller/store owner's perspective, the five components that affect Marketplace business competition in the digital marketing era are rivalry of competitors, bargaining power of customers, the threat of new entrants, bargaining power of suppliers, the threat of substitute product, and service. Meanwhile, according to buyers of goods in the marketplace, the five components that affect Marketplace business competition in the digital marketing era are rivalry of competitors, the threat of substituted products and services, bargaining power of customers, and bargaining power of suppliers a threat of new entrants. From the results of this study, it is suspected that Michael Porter's theory can be applied in business competition in the digital era. For further research, the author will discuss whether it is true that Michael Porter's approach is still relevant to be applied according to practitioners and marketing strategists.
\end{abstract}

\section{Keywords:}

competitive forces; marketplace; michael porter

\section{Introduction}

Technological developments accompanied by internet network access have brought significant changes in people's lifestyles. This can be seen from changes in consumption patterns of needs and desires coupled with the mobility of people in increasingly dense urban areas. It also makes us aware that people need supporting facilities to meet their needs through internet technology, saving time, cost, and effort. The presence of a marketplace is felt to answer the community's needs that have been described above. The marketplace is believed to support online shopping in the world. The presence of the market also makes transactions more accessible and effective (Adirinekso et al., 2021); therefore, the number of marketplace business developments in the world has increased significantly.

Based on data taken from Databoks.co.id in April 2021, Indonesia is also listed as one of the countries with the most significant growth in digital electronic commerce transactions in the world and has the most significant digital transaction value in Southeast Asia and is predicted to continue to grow (Databoks, 2021). Seeing the excellent business opportunity in the marketplace, many multinational and domestic companies compete to create a market that is more attractive to consumers and strive to create superior value compared to other competitors, namely by creating a competitive advantage, building a good brand image, and other components that will be described in writing this thesis. 
A phenomenon taken from data on the I price website and analyzed by CLSA Indonesia in 2019 noted that Shopee had 72,973,300 monthly visitors with a transaction value of approximately $\$ 7,200,000,000$, Tokopedia had $67,900,000$ monthly visitors with a transaction value of approx. as much as $\$ 10,600,000,000$ and Bukalapak with monthly visitors of $32,263,300$ with a transaction value of approximately $\$ 3,000,000,000$. From this data, it can be seen that in 2019 the Shopee marketplace was the marketplace that had the highest number of monthly visitors. Still, Tokopedia was the leader of the largest transaction value compared to other marketplaces.

The research gap from this research is that every marketplace must have innovation capabilities and competencies that can be used to become the primary weapon in facing competition because of the emergence of new competitors that indirectly bring change, still have a significant influence, all marketplace services have the threat of substitute products especially again when the pandemic is over. Below are some gaps from journal analysis and other research related to Michael Porter's theory and similar marketplace business competition:

1. Analysis of Competitive Force on the Zalora.co.id system in the Elinvo Journal Vol. 1, No. 2, May 2016, where the author analyzes how strong Zalora's competitive strategy is with Michael Porter's theory.

2. Comparative analysis of the Shopee and Tokopedia applications researched by Adam Arnap et al. in 2019 in Yogyakarta, which discussed the comparison of the Tokopedia and Shopee marketplaces in developing their applications.

3. Competitiveness of E-Commerce Companies and Integrated Approach in Journal of International E-Business and Government Studies Vol. 4 No. 1 of 2012 where research analyzes the factors that influence the competitiveness of companies through managerial skills and about e-commerce in Turkey.

These phenomena and the emergence of research gaps are interesting for further analysis and are one part that other researchers have not studied. By using Michael Porter's theory, researchers will analyze the main components that make a marketplace a leader in this line of business and other features used to maintain their business existence in the marketplace business competition as well as the relevance of the theory of the competitive force put forward by Michael Porter in the digital marketing era.

\section{Review of Literature}

\subsection{Michael Porter Theory}

This theory is a theoretical model created by Michael Porter, an expert and professor at Harvard University in 1979. This theory was developed to describe a framework as an analysis of the development of a business that can be used for large and small companies, which are already running or just about to start. The components of Michael Porter's theory of competitive force are as follows:

\section{Bargaining Power of Customer}

The focus of this site lies in buyer analysis, where buyers play a significant role in buying and selling activities. However, this side is more directed to the buyer's choice of existing products, where buyers can only purchase products from this company, or many buyers have many options to buy the same product as production from other companies because there are many circulating in the market. In this section, we can see customer loyalty, where buyers bare e entirely loyal toal to a company's buying and selling process. (Galih, 2016) 


\section{Bargaining Power of Supplier}

In this section, suppliers can use their bargaining power against buyers by increasing prices or lowering the quality of products/services. Companies will try to get raw materials as cheap as possible with high quality to win the competition in the market (Galih, 2016).

\section{Threat of New Entrants}

As time goes on and business developments, the threat of competition does not only arise from old competitors. The entry of new players in the same industry will make the competition tighter and risk lowering the company's profit. In this theory, there are six primary sources of barriers to entry of new entrants, namely, economies of scale, product differentiation, capital requirements, cost losses that are not influenced by company size, access to distribution channels, government policies (Galih, 2016).

\section{Threat of Substitutes}

The existence of substitute products/services can limit the amount of potential profit earned in an industry. The more attractive alternative prices offered by substitute products, the more stringent the restrictions on an industry's profits will be. This section can be concluded that the creation of substitute products/services dramatically affects the company's income (Galih, 2016).

\section{Rivalry of Competitors}

In this section, these forces are the main determinants as firms must compete aggressively for large market share. A company will benefit more if the company's position is strong and the level of market competition is low, coupled with customer loyalty which is getting better day by day (Galih, 2016).

\subsection{Digital Marketing}

Digital marketing uses interactive internet media and technology to connect consumers and companies and share information and communication directly. This shows that digital marketing helps connect the two parties in marketing activities, both prospective consumers and companies, so buying and selling activities are easy to do (Coviello, Milley, and Marcollin, 2001).

\subsection{Marketplace}

The marketplace is applying digital technology to achieve marketing goals (Smith, 2005). The marketplace is an internet-based online media used for business transactions where buyers can find their needs by bringing together sellers according to criteria with circulating market prices (Opiida, 2014). The number of partners or partners in the marketplace has also given birth to many marketplaces and e_business companies (Purba J. T., Budiono, Rajagukguk, Samosir, \& Adirinekso, 2021).

\section{Research Methods}

In this study, the object of this research is limited to Michael Porter's competitive force component that influences the marketplace to become a market leader in the digital marketing era. The research period is from August - November 2021, then the sample criteria in this study include Indonesian citizens, domiciled in Jakarta, and have at least one marketplace application. The data analysis methods in this study include the Validity and Reliability Test, Factor Analysis Test in the form of KMO and Bartlett's test, Anti Image Matrics test, Communalities test, Component Matrics test, Rotated Component Matrics test. 


\section{Result and Discussion}

\subsection{Validity and Reliability Test}

The results of the validity test on the shop owner show that the Corrected item-total Correlation value entirely has a value above 0.30 ; it can be concluded that all the variables used in this study are valid so that they can be measured the extent of accuracy and accuracy. Similar results were also seen on the buyer's part, so it can be concluded that all the variables used in this study are valid to measure the extent of accuracy and accuracy.

The reliability test results on the shop owner showed the Cronbach's Alpha value above 0.60 , so it can be concluded that all the variables that have been tested can be said to be reliable or accurate, trustworthy, and able to reveal essential information. Similar results were also shown on the part of buyers.

\subsection{Interpretation of Factor Analysis of the Store Owner's Part a. Understanding of Rivalry Factor Analysis Among Existing Competitors}

The results of the KMO test on this variable have a value of $0.000<0.05$. So it can be said that the indicators of the tested variables are worthy of being used for further research. The results of the Anti Image Matrics test on this variable have a value of more than 0.5, where RAE 3 has a value of 0.912 , RAE 4 has a value of 0.791 , RAE 5 has a value of 0.815 , RAE 6 has a value of 0.731 and RAE 7 has a value of 0.740 . So it can be said that the indicators of the tested variables are correlated with each other and deserve to be used for factor analysis tests. The communalities test values for these variables each have a value of more than 0.5. This shows that brand ambassadors, flash sales, discounts/free shipping, appearance, and application updates can explain the RAE variable. The value of the matrix component in this variable shows that there is only a 1 -factor component and has a correlation value of more than 0.5 from other variables. The rotated value of the matrix component in this questionnaire is empty because the matrix component only shows 1 part. So this test only ensures that some of the factors studied/observed only fall into the same variable.

Based on field data in the form of a questionnaire filled out by shop owners and the results of SPSS analysis, competition among existing competitors can be seen from several indicators such as brand ambassadors, flash sales, discounts/free shipping, display, and application updates. In line with international journals, which say that when competition among competitors is high, competitors tend to be actively involved in advertising and price wars that are detrimental to the business, and competition will also be more intense when the company remains in the industry even though its profits have dropped drastically (Business to You Industry Analysis, 2016).

\section{b. Interpretation of Bargaining Power of Supplier Factor Analysis}

The results of the KMO test on this variable have a value of $0.000<0.05$. So it can be said that the indicators of the tested variables are worthy of being used for further research. The Anti Image Matrics test results on this variable have a value of more than 0.5 where the importance of BPS 1 is 0.762 ; BPS 2 is 0.655 , BPS 4 is 0.568 , and BPS 6 is 0.596 , and BPS 7 is 0.559 . Therefore, it can be said that the indicators of the tested variables are correlated with each other and are suitable for testing factor analysis. The communalities test value on this variable is more than 0.5. This shows that this BPS variable can be explained by product quality, price service variations, store discounts/vouchers, competition between the same business lines, and store ratings. The value of the component matrix on the questionnaire filled in by the owner of the marketplace shop shows that 2 component factors influence the 
variables, and each variable has a correlation value/relationship between variables. The rotated component matrix value in the questionnaire filled in by the marketplace store owner is only to ensure that two variable components influence the factor where the first component is discounts, store vouchers, and store ratings, and the second component is product quality, price service variations, and competition between different business lines. Same.

Based on field data in the form of a questionnaire filled out by shop owners and SPSS analysis results, competition in this variable can be seen from several indicators such as discounts, store vouchers, ratings, product quality, price variations, and competition in the same line of business. In line with international journals that support the potential to play prices and increase the quality of goods or services will impact industry profitability (Business to You Industry Analysis, 2016).

\section{c. Interpretation of Bargaining Power of Customer Factor Analysis}

The results of the KMO test on this variable have a value of $0.000<0.05$. So it can be said that the indicators of the tested variables are worthy of being used for further research. The Anti Image Matrics test results on this variable have a value of more than or equal to 0.5, where the BPC values of 4 and 5 are 0.500 . Therefore, it can be said that the indicators of the tested variables are correlated with each other and are suitable for testing factor analysis. The communalities test value on this variable is more than 0.5 . This shows that service updates and ease of transaction can explain the BPC variable. The value of the matrix component in this variable indicates that there is only a 1 -factor component and has a correlation value of more than 0.5 from other variables. The rotated value of the matrix component in this questionnaire is empty because the matrix component only shows 1 component. So this test only ensures that some of the factors studied/observed only fall into the same variable.

Based on field data in the form of a questionnaire filled out by shop owners and the results of SPSS analysis, competition in this variable can be seen from several indicators such as service updates and transaction convenience. This is supported by international journals, which say that customers have many alternatives to buy a product/service in the digital era. Therefore, companies must implement loyalty through services that make it easier for consumers to transact (Business to You Industry Analysis, 2016).

\section{d. Interpretation of Threat of Substitute Product and Service Factor Analysis}

The results of the KMO test on this variable have a value of $0.000<0.05$. So it can be said that the indicators of the tested variables are worthy of being used for further research. The Anti Image Matrics test results on this variable have a value of more than 0.5 where the value of the RSP 1 variable is 0.860 , TSP 2 is 0.704 , TSP 3 is 0.838 , and TSP 5 is 0.798 . Therefore, it can be said that the indicators of the tested variables are correlated with each other and are suitable for testing factor analysis. The communalities test value on this variable is more than 0.5. This shows that this TSP variable can be explained by factors such as the ease with which new stores can join, service excellence, features in the application, and facilities in the marketplace. The value of the matrix component in this variable shows that there is only a 1 -factor component and has a correlation value of more than 0.5 from other variables. The rotated value of the matrix component in this questionnaire is empty because the matrix component only shows 1 component. So this test only ensures that some of the factors studied/observed only fall into the same variable.

Based on field data in the form of a questionnaire filled out by shop owners and the results of SPSS analysis, competition in substitute products/services can be seen from several indicators such as the ease with which new stores can join, service excellence, features in the 
application and facilities. The data is supported by international journals, which reveal that a marketplace must have a distinct advantage. These advantages can be in existing features and facilities (Business To You Industry Analysis, 2016).

\section{e. Interpretation of Threat of New Entrants. Factor Analysis}

The results of the KMO test on this variable have a value of $0.000<0.05$. So it can be said that the indicators of the tested variables are worthy of being used for further research. The Anti Image Matrics test results on this variable have a value of more than 0.5 where the variable TNE 2 has a value of 0.719 , TNE 3 has a value of 0.832 , TNE 4 has a value of 0.845 , and TNE 5 has a value of 0.720 . Therefore, it can be said that the indicators of the tested variables are correlated with each other and are suitable for testing factor analysis. The communalities test value on this variable is more than 0.5 . This shows that the TNE variable can be explained by factors such as the ease of imitating similar marketplaces, consumers who have an open and critical mind. The value of the matrix component in this variable shows that there is only a 1 -factor component and has a correlation value of more than 0.5 from other variables. The rotated value of the matrix component in this questionnaire is empty because the matrix component only shows 1 component. So this test only ensures that some of the factors studied/observed only fall into the same variable.

Based on field analysis in the form of a questionnaire filled out by shop owners and the results of SPSS analysis, competition in this variable can be seen from the indicators of the ease of imitating similar marketplaces and consumers who have an open and critical mind. An international saying supports that new entrants' entry brings the capacity and desire to gain market share. One of the obstacles to hindering the entry of new entrants is the significant investment, government policies, and limited access to distribution channels (Business To You Industry Analysis, 2016).

\section{f. Overall Factor Analysis Interpretation}

The results of the KMO test on this variable have a value of $0.000<0.05$. So it can be said that the indicators of the tested variables are worthy of being used for further research. The results of the Anti Image Matrics test on this variable have a value of more than 0.5 where the BPS variable has a value of 0.712 , BPC has a value of 0.738 , TNE has a value of 0.607 , TSP has a value of 0.676 , RAE has a value of 0.640 . Therefore, it can be said that the indicators of the tested variables are correlated with each other and are suitable for testing factor analysis. The communalities test value on this variable is more than 0.5 . This shows that the Five Forces variable can be explained by rivalry among existing competitors, suppliers' bargaining power, customer's bargaining power, the threat of substituted $\mathrm{p}$ and, and new entrants. The value of the matrix component in this variable shows that there is only a 1factor component and has a correlation value of more than 0.5 from other variables. The rotated value of the matrix component in this questionnaire is empty because the matrix component only shows 1 component. So this test only ensures that some of the factors studied/observed only fall into the same variable. In this sect, all indicators affect the Five Forces business competition, in line with the theory expressed by Michael Porter in the framework published in the Harvard Business Review in 1979.

\subsection{Buyer's Part Factor Analysis Interpretation}

\section{a. Interpretation of Rivalry Factor Analysis Among Existing Competitors}

The results of the KMO test on this variable have a value of $0.000<0.05$. So it can be said that the indicators of the tested variables are worthy of being used for further research. The results of the Anti Image Matrics test on this variable have a value of more than 0.5 where RAE 1 has a value of 0.626 , RAE 3 has a value of 0.572 , RAE 5 has a value of 0.744 , 
RAE 6 has a value of 0.733 and RAE 7 has a value of 0.765 . Therefore, it can be said that the indicators of the tested variables are correlated with each other and are suitable for testing factor analysis. The communalities test value on this variable is more than 0.5 . This shows that disthe RAE variable can explain discounts/free shipping, various payment services, customer service, brand ambassadors, and service updates. The value of the component matrix on the questionnaire filled out by the buyer shows that 2 component factors affect the variables, and each variable has a correlation value/relationship between variables. The rotated component matrix value in the questionnaire filled out by the buyer ensures that two variable components influence the factor where. The first component is discount/free shipping and various payment services, and the second component is customer service, brand ambassador, and service updates.

Based on field data in the form of a questionnaire filled out by buyers and the results of SPSS analysis, the competition is seen in this variable can be found in several indicators such as discounts/free shipping, various payment services, customer service, brand ambassadors, and service updates. The data above is in line with international journals, which say that competition in an industry is caused by several factors such as influencers, price discounts, and other factors that position themselves better to fight against other players such as customer service and various payment services (Competitive Position Analysis Explained, 2019).

\section{b. Interpretation of Bargaining Power of Supplier Factor Analysis}

The results of the KMO test on this variable have a value of $0.000<0.05$. So it can be said that the indicators of the tested variables are worthy of being used for further research. The results of the Anti Image Matrics test on this variable have a value of more than 0.5 where BPS 1 has a value of 0.831 ; BPS 2 has a value of 0.847 , BPS 3 has a value of 0.783 , BPS 4 has a value of 0.734 , BPS 5 has a value of 0.864 , BPS 6 has a value of 0.870 , CPM 7 has a value of 0.899 . Therefore, it can be said that the indicators of the tested variables are correlated with each other and are suitable for testing factor analysis. The communalities test value on this variable is more than 0.5. This shows that this BPS variable can be explained by product quality, reasonable prices, freedom to choose products, friendly suppliers, store ratings, discounts/prices, vouchers. The value of the component matrix on the questionnaire filled out by the buyer shows that 2 component factors affect the variables, and each variable has a correlation value/relationship between variables. The rotated component matrix value in the questionnaire filled out by the buyer ensures that two variables influence the factors where. The first component is product quality, reasonable prices, flexibility in choosing products, friendly suppliers, store ratings, and the second component is discounts/prices and vouchers.

Based on field data in the form of a questionnaire filled out by buyers and the results of SPSS analysis, competition in this variable can be seen from several indicators such as product quality, reasonable prices, freedom to choose products, friendly suppliers, store ratings, discounts/fees, and vouchers. The data is also in line with international journals that support that having unique products at reasonable prices, switching programs such as discounts/prices, values, and maintaining relationships with customers will strengthen suppliers' bargains more robust (Competitive Position Analysis Explained, 2019).

\section{c. Interpretation of Bargaining Power of Customer Factor Analysis}

The results of the KMO test on this variable have a value of $0.000<0.05$. So it can be said that the indicators of the tested variables are worthy of being used for further research. The Anti Image Matrics test results on this variable have a value of 0.5 where BPC 2 has a 
value of 0.698 , BPC 3 has a value of 0.703 , BPC has a value of 0.733 BPC 5 has a value of 0.738. Therefore, it can be said that the indicators of the tested variables are correlated with each other and are suitable for testing factor analysis. The communalities test value on this variable is more than 0.5 . This shows that this BPC variable can be explained by factors such as products that suit the needs, competitive prices, service updates to make it easier for consumers, and variations in payment services. The value of the matrix component in this variable shows that there is only a 1 -factor component and has a correlation value of more than 0.5 from other variables. The rotated value of the matrix component in this questionnaire is empty because the matrix component only shows 1 component. So this test only ensures that some of the factors studied/observed only fall into the same variable.

Based on field data in the form of questionnaires filled out by buyers and the results of SPSS analysis, competition in this variable can be seen from several indicators such as products that suit their needs, competitive prices, service updates to make it easier for consumers and variations in payment services. This data is also supported by international journals that say that buyers' bargaining power tends to be more sensitive to competitive prices and is not concerned with the quality and convenience of consumers in shopping (Competitive Position Analysis Explained, 2019).

\section{d. Interpretation of Threat of Substitute Product and Service Factor Analysis}

The results of the KMO test on this variable have a value of $0.000<0.05$. So it can be said that the indicators of the tested variables are worthy of being used for further research. The Anti Image Matrics test results on this variable have a value of 0.5 where TSP 1 has a value of 0.624 ; TSP 2 has a value of 0.611 , and TSP 5 has a value of 0.781 . Therefore, it can be said that the indicators of the tested variables are correlated with each other and are suitable for testing factor analysis. The communalities test value on this variable is more than 0.5. This shows that consumers who desire to move to other marketplaces can explain this TSP variable. These new marketplaces provide lower prices and the comparative nature of consumers. The value of the matrix component in this variable shows that there is only a 1factor component and has a correlation value of more than 0.5 from other variables. The rotated value of the matrix component in this questionnaire is empty because the matrix component only shows 1 component. So this test only ensures that some of the factors studied/observed only fall into the same variable.

Based on field data in the form of a questionnaire filled out by buyers and the results of SPSS analysis, competition in this variable can be seen from several indicators. One of them is the desire to move to another marketplace, new marketplaces that provide lower prices, and the nature of comparing consumers. This was later supported by an international journal which said that the marketplace must dare to develop itself and offer better services than other marketplaces to retain existing customers (Competitive Position Analysis Explained, 2019).

\section{e. Interpretation of Threat of New Entrants. Factor Analysis}

The results of the KMO test on this variable have a value of $0.000<0.05$. So it can be said that the indicators of the tested variables are worthy of being used for further research. The results of the Anti Image Matrics test on this variable have a value of 0.5 where TNE 1 has a value of 0.631 , TNE 2 has a value of 0.762 , TNE 3 has a value of 0.614 , TNE 4 has a value of 0.651 , TNE 5 has a value of 0.659 . Therefore, it can be said that the indicators of the tested variables are correlated with each other and are suitable for testing factor analysis. The communalities test value on this variable is more than 0.5 . This shows that the TNE variable can be explained by factors such as the possibility for consumers to move to other 
marketplaces, the ease of marketplace to be imitated by other marketplaces, and consumers' open and critical nature. The value of the component matrix on the questionnaire filled in by the buyer shows that 2 component factors influence the variables, and each variable has a correlation value. The value of the rotated component matrix on the questionnaire filled out by the buyer ensures that 2 component variables influence the factor where the first component is the possibility of consumers moving to other marketplaces.

Based on field data in the form of a questionnaire filled out by buyers and the results of SPSS analysis, competition in this variable can be seen from several indicators such as the possibility for consumers to move to other marketplaces, the ease of the market to be imitated by other marketplaces and the open and critical nature of consumers. This is then supported by international journals, which say that new entrants bring the capacity and desire to gain market share. The things that hinder the entry of new entrants are economies of scale, such as creating a marketplace that is quite tricky and extensive enough capital and product differentiation is difficult to reach by the market (Competitive Position Analysis Explained, 2019).

\section{f. Overall Factor Analysis Interpretation}

The results of the KMO test on this variable value $0.000<0.05$. Therefore, it can be said that the indicators of the tested variables are feasible to be used as material for further research. The Anti Image Matrics test results on this variable have a value of 0.5 where BPS has a value of 0.562 , BPC has a value of 0.563 , TNE has a value of 0.648 , TSP has a value of 0.697 , and RAE has a value of 0.788 - correlated and feasible to use for testing factor analysis. The communalities test on this variable has a value of more than 0.5 . This shows that the Five Forces variable can be explained by rivalry among existing competitors, suppliers' bargaining power, substitute products and services, and the threat of new entrants. The value of the component matrix on the questionnaire filled in by the buyer shows that 2 component factors influence the variables, and each variable has a correlation value. The rotated component matrix value in the questionnaire filled out by the buyer ensures that 2 component variables influence the factor. The first component is the bargaining power of suppliers and customers. The second component is rivalry among existing, threat of substituted products and services $\&$ the art of new entrants.

So, it can be concluded that all indicators affect the Five Forces business competition, in line with the theory expressed by Michael Porter in the framework published in the Harvard Business Review in 1979 to analyze the business competition.

Table 1. Store Owner and Buyer Comparative Analysis

\begin{tabular}{|c|c|c|c|}
\hline & Store & & \\
\hline $\begin{array}{l}\mathrm{K} z \mathrm{v} \\
\mathrm{Am} \\
\mathrm{Ex} \\
\mathrm{Con}\end{array}$ & $\begin{array}{l}\text { Brand Ambassador, } \\
\text { Flash Sale, } \\
\text { Discounts/Free } \\
\text { Shipping, Display \& } \\
\text { Application Updates are } \\
\text { one component that } \\
\text { forms a variable rivalry } \\
\text { among existing } \\
\text { competitors }\end{array}$ & $\begin{array}{l}\text { Discounts/free shipping } \\
\text { and various services } \\
\text { become component } 1 \text {, and } \\
\text { customer service, brand } \\
\text { ambassadors, and service } \\
\text { updates become } \\
\text { component } 2 \text { that forms a } \\
\text { variable rivalry among } \\
\text { existing competitors }\end{array}$ & $\begin{array}{l}\text { Flash sale is not an } \\
\text { indicator for buyers to win } \\
\text { this business competition } \\
\text { Buyers prioritize service } \\
\text { updates and customer } \\
\text { service that facilitates } \\
\text { transaction activities } \\
\text { compared to the } \\
\text { marketplace application. }\end{array}$ \\
\hline
\end{tabular}




\begin{tabular}{|c|c|c|c|}
\hline $\begin{array}{l}\text { Bargaining } \\
\text { Power of } \\
\text { Supplier }\end{array}$ & $\begin{array}{l}\text { Discounts, vouchers, } \\
\text { store ratings are } \\
\text { component 1, and } \\
\text { product quality, } \\
\text { variations in price } \\
\text { services, and competition } \\
\text { between the same line of } \\
\text { business are components } \\
\text { two that affect the } \\
\text { variable bargaining power } \\
\text { of suppliers. }\end{array}$ & $\begin{array}{l}\text { Product quality, price } \\
\text { reasonableness, flexibility } \\
\text { in choosing products, } \\
\text { friendly suppliers, store } \\
\text { ratings are component } 1 \text {, } \\
\text { and discounts/rebates and } \\
\text { vouchers are component } 2 \\
\text { that affect the variable } \\
\text { bargaining power of } \\
\text { suppliers. }\end{array}$ & $\begin{array}{l}\text { The shop owner prioritizes } \\
\text { the variety of service } \\
\text { prices, and the way to win } \\
\text { the competition between } \\
\text { the same line of business } \\
\text { in line with what buyers } \\
\text { want is price fairness. } \\
\text { On the other hand, buyers } \\
\text { also prioritize other aspects } \\
\text { such as shopping } \\
\text { convenience through the } \\
\text { friendliness of suppliers } \\
\text { and the freedom to choose } \\
\text { products. }\end{array}$ \\
\hline $\begin{array}{l}\text { Bargaining } \\
\text { Power of } \\
\text { Customer }\end{array}$ & $\begin{array}{l}\text { Economical prices and a } \\
\text { variety of product } \\
\text { choices are one } \\
\text { component that affects } \\
\text { the variable bargaining } \\
\text { power of customers }\end{array}$ & $\begin{array}{l}\text { Products that meet needs, } \\
\text { competitive prices, service } \\
\text { updates, and variations in } \\
\text { payment services are one } \\
\text { component that affects the } \\
\text { variable bargaining power } \\
\text { of customers }\end{array}$ & $\begin{array}{l}\text { Shop owners try their best } \\
\text { to provide economical } \\
\text { prices, while buyers } \\
\text { continue to compare offers } \\
\text { from other marketplaces } \\
\text { so that competitive price } \\
\text { indicators must also be } \\
\text { considered. } \\
\text { Products that suit other } \\
\text { needs and services also } \\
\text { influence buyers in making } \\
\text { decisions, while the Store } \\
\text { Owner does not emphasize } \\
\text { this. }\end{array}$ \\
\hline $\begin{array}{l}\text { The threat } \\
\text { of } \\
\text { Substitute } \\
\text { Product and } \\
\text { Service }\end{array}$ & $\begin{array}{l}\text { The ease of joining new } \\
\text { stores, service excellence, } \\
\text { features in the } \\
\text { application, and other } \\
\text { marketplace facilities are } \\
\text { factors that affect the } \\
\text { threat of substituted } \\
\text { product and service } \\
\text { variables. }\end{array}$ & $\begin{array}{l}\text { The feeling of consumers } \\
\text { to move and try new } \\
\text { marketplaces, the attitude } \\
\text { of comparing and offering } \\
\text { cheaper from other } \\
\text { marketplaces is one } \\
\text { component that affects the } \\
\text { threat of substituted } \\
\text { products and services } \\
\text { variables. }\end{array}$ & $\begin{array}{l}\text { In this section, the Store } \\
\text { Owner must adequately } \\
\text { utilize the features in the } \\
\text { marketplace to provide its } \\
\text { advantages and appeal so } \\
\text { that consumers do not } \\
\text { move and try to other } \\
\text { stores/marketplaces. } \\
\text { Consumer attitudes that } \\
\text { are critical and compared } \\
\text { can also be overcome with } \\
\text { point number } 1 \text { above. }\end{array}$ \\
\hline $\begin{array}{l}\text { The threat } \\
\text { of New } \\
\text { Entrants }\end{array}$ & $\begin{array}{l}\text { Ease of imitating similar } \\
\text { marketplaces, open- } \\
\text { minded and critical } \\
\text { consumers are one } \\
\text { component that } \\
\text { influences the threat of } \\
\text { new entrants }\end{array}$ & $\begin{array}{l}\text { The possibility of } \\
\text { consumers to move to } \\
\text { other marketplaces and the } \\
\text { ease of the market to be } \\
\text { imitated, and the open } \\
\text { nature of consumers } \\
\text { become component } 1 \\
\text { while the critical nature of } \\
\text { consumers becomes } \\
\text { component } 2 \text { that affects } \\
\text { the variable threat of new } \\
\text { entrants }\end{array}$ & $\begin{array}{l}\text { Consumers open and } \\
\text { critical nature is the same } \\
\text { indicator for the buyer and } \\
\text { seller side to win the } \\
\text { business competition. In } \\
\text { this variable, the difference } \\
\text { is that the shop owner tries } \\
\text { so that his shop is not } \\
\text { easily imitated. At the same } \\
\text { time, the buyer can move } \\
\text { to another marketplace } \\
\text { because of his critical and } \\
\text { open attitude. }\end{array}$ \\
\hline
\end{tabular}




\begin{tabular}{|c|c|c|}
\hline & $\begin{array}{l}\text { Variables Rivaly Among } \\
\text { Existing Competitors, } \\
\text { Bargaining Power of Supplier } \\
\text { \& Customer, Threat of } \\
\text { Substituted Product and } \\
\text { Service and Threat of New } \\
\text { Entrants become } 1 \text { component } \\
\text { that affects the marketplace } \\
\text { business competition in } \\
\text { Jakarta }\end{array}$ & $\begin{array}{l}\text { The variable Bargaining } \\
\text { Power of Supplier and } \\
\text { Customer becomes } \\
\text { component 1, and the } \\
\text { variable Rivalry Among } \\
\text { Existing Competitors, } \\
\text { Threat of Substituted } \\
\text { Product and Service and } \\
\text { Threat of New Entrants } \\
\text { becomes component } 2 \text { that } \\
\text { affects the marketplace } \\
\text { business competition in } \\
\text { Jakarta }\end{array}$ \\
\hline Outline & $\begin{array}{l}\text { Where the variable that } \\
\text { has the highest } \\
\text { component matrix value } \\
\text { in influencing business } \\
\text { competition is Rivalry } \\
\text { Among Existing } \\
\text { Competitors with a value } \\
\text { of } 0.914 \text {, followed by } \\
\text { Bargaining Power of } \\
\text { Customer with a value of } \\
0.855 \text {, Threat of New } \\
\text { Entrants with a value of } \\
0.813 \text {, Bargaining Power } \\
\text { of Suppliers with a value } \\
\text { of } 0.802 \text { and the last is } \\
\text { Threat of Substituted } \\
\text { Product and Service with } \\
\text { a value of } 0.742\end{array}$ & $\begin{array}{l}\text { Where the variable that has } \\
\text { the highest component } \\
\text { matrix value in influencing } \\
\text { business competition is } \\
\text { Rivalry Among Existing } \\
\text { Competitors with a value } \\
\text { of 0.749, followed by } \\
\text { Threat of Substituted } \\
\text { Products and Service with } \\
\text { a value of 0.692, } \\
\text { Bargaining Power of } \\
\text { Customer with a value of } \\
0.691 \text {, Bargaining Power of } \\
\text { Suppliers with a value of } \\
0.676 \text { and the last is Threat } \\
\text { of New Entrants with a } \\
\text { value of } 0.627\end{array}$ \\
\hline
\end{tabular}

\section{Conclusion}

So it can be concluded that the main component of Marketplace in winning a business competition through quantitative testing is the Rivalry of Competitor considering a proverb that says "consumer is king." Therefore, consumer convenience must be improved so as not to move to other Marketplaces. Meanwhile, the position of different components that affect the competitive forces in the marketplace competition is divided into two sides, namely.

\begin{tabular}{|c|l|l|}
\hline Component & \multicolumn{1}{|c|}{ Store Owner } & \multicolumn{1}{|c|}{ Buyer } \\
\hline 1 & Rivalry Among Existing Customer & Rivalry Among Existing \\
\hline 2 & Bargainning Bargainingstomer & $\begin{array}{l}\text { The threat of Substituted Product and } \\
\text { Service }\end{array}$ \\
\hline 3 & The threat of New Entrants & Bargaining Power of Customer \\
\hline 4 & Bargaining Power of Supplier & Bargaining Power of Supplier \\
\hline 5 & $\begin{array}{l}\text { The threat of Substituted Product and } \\
\text { Service }\end{array}$ & The threat of New Entrants \\
\hline
\end{tabular}




\section{References}

Adirinekso, G. P., Purba, J. T., Budionno, S., \& Rajaguguk, P. (2021). How Brand Image Mediated Sales Promotion and Price to Impact Shopee Consumer's Decision? The Case of Urban Worker in Jakarta. Proceedings of the International Conference on Industrial Engineering and Operations Management Sao Paulo, Brazil.

Adirinekso, G. P., Purba, J. T., Budionno, S., \& Rajaguguk, P. (2020). The Role of Price and Service Convenience on Jakarta's Consumer Purchase Decision in Top 5 Marketplace Mediated by Consumer's Perceived Value. Proceedings of the 5th NA International Conference on Industrial Engineering and Operations Management (pp. 1808 - 1819). Detroit, Michigan, USA: IEOM Society International

Adirinekso, G. P., Purba, J. T., \& Budiono, S. (2020). Measurement of Performance, Effort, Social Influence, Facilitation, Habit and Hedonic Motives toward Pay later Application Intention: Indonesia Evidence. Proceedings of the 2nd African International Conference on Industrial Engineering and Operations Management (pp. 208 - 219). Harare, Zimbabwe: IEOM Society International.

Arnap, A., Dewi, M., \& Kom, M. (n.d.). Analisa Perbandingan Aplikasi Shopee dan Tokopedia. Amikom Yogyakarta.

Adams, C. (2010). Journal of Internet Banking and Commerce. In JIBC15(1)

Aggarwal, P., Mittal, N., Kumar, S., \& Somaiya, K. J. (n.d.). Comparison of E-Commerce websites using Sentiment Analysis.

Aziz, U. A., Wibisono, A., \& Nisafani, A. S. (2019). Measuring the quality of e-commerce websites using analytical hierarchy process. Telkomnika (Telecommunication Computing Electronics and Control), 17(3), 1202-1208.

Bakos, D, dkk. (2005). The Impact of E-Commerce on Competition in the Retail Brokerage Industry. Informs, 16(4).

Chrystiantari, M. C., \& Suyanto, A. (2020). Analisis Faktor-Faktor Pembentuk Customer Perceived Value E-Commerce Di Indonesia. Jurnal Mitra Management, 1(2), 215-224.

Čiarnienè, R., \& Stankevičiūtè, G. (2015). Theoretical Framework of E-Business Competitiveness. Procedia - Social and Behavioral Sciences, 213, 734-739.

Chen, Q., \& Zhang, N. (2015). Does e-commerce provide a sustained competitive advantage? An investigation of survival and sustainability in growth-oriented enterprises. Sustainability (Switzerland), 7(2), 1411-1428.

Dumitrache, M. (2010). E-Commerce Applications Ranking. In Informatica Economic, 14(2).

Darwis, Y. (2013). The Urgency of Communication Media (E-Commerce) in Indonesia's Creative Industry as an Effort to Increase International Business Competition. In The International Journal of Organizational Innovation

Ekarini, F. (2016). Analysis Competitive Forces and Competitive Strategy pada Sistem Informasi “Zalora.co.id." In Jurnal Electronics, Informatics, 1(2).

Febrian, A. F. (2017). Analysis of Porter's Generic Strategies Theory to Improve Competitiveness. https://www.researchgate.net/publication/317559198

Fawzy, M. A. (2018). E-Commerce Adoption and an Analysis of The Popular E-Commerce Business Sites in Malaysia. In Journal of Internet Banking and Commerce,23(1).

Gloria Narida, M. (2019). Brand Image dalam Persaingan Iklan E-commerce dengan Menggunakan Brand Ambassador. In Journal Of Media and Communication Science), $3(1)$.

Kostoska, O., Hristoski, I., Kotevski, Z., \& Dimovski, T. (2017). Factors Affecting the Competitiveness of e-Commerce Firms: A Critical Appraisal. IBANESS.https://www.researchgate.net/publication/314311907 
Lecturer Valentin Mihai Leoveanu, P. D. (2019). 52 Management and the economic crisis Can Mobile Payments Boost E-Commerce Business in Romania. Management and Economic Crysis,30.

Mangiaracina, R., \& Perego, A. (2009). Journal of Internet Banking and Commerce The eCommerce Customer Journey: A Model to Assess and Compare the User Experience of the eCommerce Websites. In Journal of Internet Banking and Commerce14(3).

Norhabiba, F., Fridha, M., Palupi, T., \& Rohimah, A. (n.d.). (2019). Hubungan Terpaan Iklan Shopee dan Tokopedia, Akses Aplikasi dan Minat Membeli Pada Mahasiswa UNTAG Surabaya. Jurnal Komunikasi dan Kajian Media3(2).

Purba Pamungkas, D. (2016). Analisis Competitive force dan Competitive Strategy Sistem Informasi Kuliner di Indonesia (Studi Kasus: Kulina.id). In Jurnal Electronics, Informatics, 1(2).

Purbasari, R., Silvya Sari, D., \& Muttaqin, Z. (n.d.). (2020).Mapping of Digital Industry Competitive Advantages: Market-Based View Approach.Review of Integrative Business \& Economics Research, 9(4).

Qiu, C., Chen, B. ;, Shao, S.-J., \& Sun, Q. (n.d.). (2003). Cultural differences in e-commerce: A comparison between the US and China. Journal of Global Information Management, 11(2).

Razzouk, N. Y., Seitz, V., \& wu, G. (2008). The attitudes of e-commerce channel members in the textile industry: An empirical perspective. Direct Marketing: An International Journal, 2(1), 20-35. https://doi.org/10.1108/17505930810863617

Ramadhani, H., \& Dirgahayu, T. (n.d.). (2021). Faktor Pemilihan E Marketplace di Indonesia dari Perspektif Penjual (Studi Kasus: Tokopedia dan Shopee).Explore 11(1).

Septiana, A. M. Analisa Daya Saing E-Commerce di Indonesia. Orangenest Incubator Network.

Sahin, C. (2012). Competitiveness of E-Commerce Companies: An Integrated Approach. International Journal Of E-Business and E-Government Studies, 4(1).

Schweitzer, H., Haucap, J., Kerber, W., \& Welker, R. (2018). Modernizing the Law on Abuse of Market Power: Report for the Federal Ministry for Economic Affairs and Energy (Germany). SSRN Electronic Journal.

Utami, A., Alamsyah, A., \& Si, S. (n.d.). (2018). Content Analysis of Indonesia E-Commerce on Facebook Page Using Social Network Analysis For Social Customer Relationship Management Effort. E-Proceeding of Management, 5(1). 